\title{
Pulsatile secretion of gonadotrophins, ovarian steroids and ovarian oxytocin during prostaglandin-induced regression of the corpus luteum in the cow
}

\author{
E. Schallenberger, D. Schams, B. Bullermann and D. L. Walters* \\ Lehrstuhl für Physiologie der Fortpflanzung und Laktation, Technische Universität München, \\ 8050 Freising-Weihenstephan, Federal Republic of Germany
}

Summary. A luteolytic dose $(500 \mu \mathrm{g})$ of cloprostenol was given on Day 12 of the oestrous cycle to 5 heifers. Blood samples were collected simultaneously from the caudal vena cava and jugular vein at 5-20-min intervals from -6 to 0 (control period), 0 to 12 and 24 to $36 \mathrm{~h}$ after PG injection. Pulses of LH were secreted concomitantly with pulses of FSH during all sampling periods. However, during the control period separate FSH pulses were detected resulting in a shorter $(P<0.01)$ interpulse interval for FSH than LH $(93$ versus $248 \mathrm{~min})$. LH and FSH pulse frequencies increased $(P<0.01)$ beginning 1-3 h after PG to interpulse intervals of 59 and $63 \mathrm{~min}$, respectively, and continued to be maintained $24-36 \mathrm{~h}$ after PG. Concomitantly there was a $2-3$-fold increase $(P<$ 0.01 ) in basal concentrations and pulse amplitude for LH (but not FSH). FSH basal concentrations and pulse amplitudes decreased $(P<0.05)$ in 3 heifers $24-36 \mathrm{~h}$ after PG. Pulsatile secretion of oestradiol was observed at frequencies similar to LH during the periods 4-12 h ( 3 heifers) and 24-36 h ( 2 heifers) after PG, respectively, resulting in higher $(P<0.05)$ mean oestradiol concentrations. Progesterone concentrations in the vena cava increased $(P<0.01) 5-10 \mathrm{~min}$ after $P$ G but decreased $(P<0.01) 67 \%$ by 20 min after PG. This decrease was followed by a rise $(P<0.05)$ beginning $2-3 \mathrm{~h}$ after $P G$ and lasting for an average of $3.3 \mathrm{~h}$. After a steady decline, basal concentrations of 1.0 $\mathrm{ng} / \mathrm{ml}$ were reached $24-36 \mathrm{~h}$ after PG. Basal oxytocin concentrations in the vena cava and jugular vein $(8.2$ and $4.2 \mathrm{pg} / \mathrm{ml})$ increased $(P<0.01)$ to reach maximum concentrations $(2029$ and $701 \mathrm{pg} / \mathrm{ml}) 5-10 \mathrm{~min}$ after PG and then decreased over a 3-5 h period and were lowest $(4.3$ and $3.2 \mathrm{pg} / \mathrm{ml}) 24-36 \mathrm{~h}$ after PG. Maximum prolactin concentrations were higher and appeared 5-10 min earlier in the jugular vein compared to the vena cava.

It is concluded that: (1) progesterone and oxytocin secretion from the corpus luteum is initially increased and then dramatically decreased by a luteolytic dose of PG; (2) the reduction of progesterone concentrations below a certain threshold level in the presence of low oestradiol concentrations probably eliminates the negative feedback effect on gonadotrophin secretion, thereby allowing the frequency and amplitude of LH pulses, and to a lesser extent the frequency of FSH pulses, to increase; and (3) the increase in FSH and LH pulse frequencies probably stimulates, after a variable period of time, the development of a large follicle that secretes increasing concentrations of oestradiol.

\footnotetext{
* Present address: M.R.C. Group in Reproductive Biology, University of Western Ontario, University Hospital, London, Ontario, Canada N6A 5A5.
} 


\section{Introduction}

Spontaneous regression of the bovine corpus luteum occurs between Days 16 and 19 of the oestrous cycle and is characterized by a decrease in basal progesterone concentrations and an increase in basal LH concentrations (Hansel \& Snook, 1970; Karg, Hoffmann \& Schams, 1970). A single i.m. injection of prostaglandin (PG) F-2 $\alpha$ or of synthetic analogues is luteolytic when administered on Days 5-16 of the oestrous cycle and results in endocrine changes similar to those observed during spontaneous luteolysis (Spicer, Ireland \& Roche, 1981). Alterations in basal hormone secretion after PG-induced regression of the corpus luteum in cows have been studied (Louis, Hafs \& Morrow, 1974a; Schams \& Karg, 1982), but the exact relationship between the pulsatile secretion of gonadotrophins and ovarian steroids has not been demonstrated.

Oxytocin is present in high concentrations in corpora lutea of ewes and cows (Wathes \& Swann, 1982; Schams, Walters, Schallenberger, Bullermann \& Karg, 1983a) and is secreted concomitantly with progesterone in a pulsatile manner during the luteal phase of the oestrous cycle (Walters, Schams \& Schallenberger, 1984). Ovarian oxytocin may be involved in regression of the corpus luteum since exogenous PG stimulates the release of oxytocin from the corpus luteum in ewes (Flint \& Sheldrick, 1983) and exogenous oxytocin stimulates the release of PG from the uterus in cows (Newcomb, Booth \& Rowson, 1977; Milvae \& Hansel, 1980).

The objective of the present study was to characterize the pulsatile secretion pattern of $\mathrm{LH}$, FSH, prolactin, progesterone, oestradiol-17 $\beta$ and ovarian oxytocin after PG-induced regression of the corpus luteum and to determine temporal relationships amongst these hormones.

\section{Materials and Methods}

Experimental animals. Five regularly cyclic heifers (18-20 months of age) of the local Braunvieh breed were used. All heifers were tethered indoors during the experiment. They were fed hay, corn silage and energy supplement twice daily and had access to water ad libitum.

Experimental procedure. Cannulae were inserted into the caudal vena cava and into the jugular vein on Day 11 of the oestrous cycle as described previously by Walters et al. (1984). Blood samples $(10 \mathrm{ml})$ were collected simultaneously from each vein every $20 \mathrm{~min}$ for $6 \mathrm{~h}$ (control period) on Day 12 of the cycle. A luteolytic dose $(500 \mu \mathrm{g}$ i.m.) of cloprostenol (a PGF- $2 \alpha$ analogue: ICI, Macclesfield, U.K.) was given after completion of the control period and blood samples were collected at 5-min intervals for $20 \mathrm{~min}, 10-\mathrm{min}$ intervals for another $20 \mathrm{~min}$ and then at 20 -min intervals until $12 \mathrm{~h}$ and again from 24 to $36 \mathrm{~h}$ after PG. All blood samples were placed into heparinized tubes, cooled, centrifuged at $4^{\circ} \mathrm{C}$ and the plasma was stored in 3 aliquots at $-20^{\circ} \mathrm{C}$ until hormone analysis.

Hormone analysis. LH (Schams \& Karg, 1969a), FSH (Schams \& Schallenberger, 1976), prolactin (Schams \& Karg, 1969b), oestradiol-17ß (Walters \& Schallenberger, 1983), progesterone (Hoffmann, Kyrein \& Ender, 1973) and oxytocin (Schams, 1983) were analysed in duplicate. A recent summary of assay characteristics for all of the above hormones has been reported by Walters et al. (1984). Vena cava blood samples were assayed for oestradiol, progesterone, oxytocin and prolactin, and jugular vein samples were assayed for LH, FSH, oxytocin and prolactin.

Statistical analysis. A pulse was determined as described by Walters et al. (1984). Data were analysed statistically by analysis of variance and Duncan's multiple range test was used to test for differences in hormone characteristics between the three time periods. 


\section{Results}

LH, FSH, prolactin, oestradiol, progesterone and oxytocin were all secreted in a pulsatile manner during the control period. However, changes in pulse amplitude and/or frequency occurred after the injection of PG for all hormones examined. Oestrus was detected between 48 and $60 \mathrm{~h}$ after PG.

$L H$

Basal concentrations and pulse amplitude were low and the interpulse interval relatively long (248 min) during the control period (Table 1; Text-figs 1 \& 2). However, beginning 1-3 h after PG

Table 1. Effect of cloprostenol (PG)-induced luteolysis on characteristics of secretion of LH, oestradiol, FSH, progesterone and oxytocin in 5 heifers

\begin{tabular}{|c|c|c|c|c|c|c|}
\hline \multirow[b]{2}{*}{ Hormone† } & \multicolumn{6}{|c|}{ Time after PG injection } \\
\hline & \multicolumn{2}{|c|}{-6 to $0 \mathrm{~h}$} & \multicolumn{2}{|c|}{0 to $12 \mathrm{~h} \S$} & \multicolumn{2}{|c|}{24 to $36 \mathrm{~h}$} \\
\hline \multicolumn{7}{|l|}{ LH } \\
\hline No. of heifers & 5 & & 5 & & 5 & \\
\hline Mean (ng/ml) & $0.5 \pm 0.03^{b}$ & & $1.4 \pm 0.1$ & & $1 \cdot 4 \pm 0.1$ & \\
\hline Basal (ng/ml) & $0.4 \pm 0.07^{b}$ & & $1.2 \pm 0.1$ & & $1 \cdot 1 \pm 0.1$ & \\
\hline Pulse amplitude $(\mathrm{ng} / \mathrm{ml})$ & $0.3 \pm 0.02^{\mathrm{a}}$ & & $0.6 \pm 0.1$ & & $0.7 \pm 0.1$ & \\
\hline Interpulse interval (min) & $248 \pm 39^{b}$ & & $59 \pm 4$ & & $53 \pm 3$ & \\
\hline \multicolumn{7}{|l|}{ Oestradiol } \\
\hline No. of heifers $\ddagger$ & 3 & 1 & 3 & 1 & 2 & 2 \\
\hline Mean $(\mathrm{pg} / \mathrm{ml})$ & $9 \cdot 0 \pm 0.6$ & $8 \cdot 5$ & $11 \cdot 3 \pm 0.9^{a}$ & $8 \cdot 0$ & $12 \cdot 1 \pm 1 \cdot 4^{\mathrm{a}}$ & $8 \cdot 8 \pm 2 \cdot 0$ \\
\hline Basal $(\mathrm{pg} / \mathrm{ml})$ & $8.0 \pm 0.5$ & - & $9.5 \pm 0.5$ & - & $10 \cdot 2 \pm 1.0$ & - \\
\hline Pulse amplitude $(\mathrm{pg} / \mathrm{ml})$ & $4.5 \pm 1.7$ & - & $3.8 \pm 0.7$ & - & $5.0 \pm 0.4$ & - \\
\hline Interpulse interval $(\mathrm{min})$ & $250 \pm 29 \mathrm{~b}$ & - & $64 \pm 3$ & - & $58 \pm 4$ & - \\
\hline \multicolumn{7}{|l|}{ FSH } \\
\hline No. of heifers & 5 & & 5 & & 3 & 2 \\
\hline Mean (ng/ml) & $61 \cdot 7 \pm 5.9$ & & $70 \cdot 7 \pm 5 \cdot 8$ & & $47 \cdot 5 \pm 4 \cdot 7^{\mathrm{a}}$ & $71 \cdot 2 \pm 8 \cdot 6$ \\
\hline Basal (ng/ml) & $52.5 \pm 5.8$ & & $58.9 \pm 4.9$ & & $42 \cdot 2 \pm 4 \cdot 4^{a}$ & $57 \cdot 1 \pm 4 \cdot 2$ \\
\hline Pulse amplitude $(\mathrm{ng} / \mathrm{ml})$ & $28 \cdot 3 \pm 4.5$ & & $25 \cdot 7 \pm 4.0$ & & $16.4 \pm 1.4^{\mathrm{a}}$ & $24 \cdot 1 \pm 4 \cdot 3$ \\
\hline Interpulse interval (min) & $93 \pm 2^{b *}$ & & $63 \pm 1$ & & $62 \pm 4$ & $63 \pm 1$ \\
\hline \multicolumn{7}{|l|}{ Progesterone } \\
\hline No. of heifersł & 4 & & 4 & & 4 & \\
\hline Mean $(\mathrm{ng} / \mathrm{ml})$ & $20 \cdot 0 \pm 4 \cdot 6^{a}$ & & $8 \cdot 5 \pm 1 \cdot 2$ & & $1.2 \pm 0.1$ & \\
\hline Basal $(\mathrm{ng} / \mathrm{ml})$ & $13.9 \pm 2.6$ & & $7.9 \pm 1.3$ & & 二 & \\
\hline Pulse amplitude $(\mathrm{ng} / \mathrm{ml})$ & $14.1 \pm 3.8$ & & $10.4 \pm 2.9$ & & - & \\
\hline Interpulse interval (min) & $95 \pm 16$ & & $75 \pm 18$ & & - & \\
\hline \multicolumn{7}{|l|}{ Oxytocin } \\
\hline No. of heifers $\ddagger$ & 3 & 1 & 3 & 1 & 3 & 1 \\
\hline Mean $(\mathrm{pg} / \mathrm{ml})$ & $8 \cdot 2 \pm 1 \cdot 2$ & $2 \cdot 3$ & $7 \cdot 6 \pm 2 \cdot 2$ & $2 \cdot 8$ & $4 \cdot 3 \pm 0 \cdot 5^{a}$ & $2 \cdot 8$ \\
\hline Basal (pg/ml) & $5 \cdot 4 \pm 0.5$ & - & 二 & - & 二 & - \\
\hline Pulse amplitude $(\mathrm{pg} / \mathrm{ml})$ & $7 \cdot 4 \pm 1 \cdot 1$ & - & - & - & - & - \\
\hline Interpulse interval (min) & $96 \pm 21$ & - & - & - & - & - \\
\hline
\end{tabular}

† Values for LH and FSH were obtained from jugular vein plasma and values for oestradiol, progesterone and oxytocin were obtained from caudal vena cava plasma; all values are mean \pm s.e.m. Values are given separately for heifers exhibiting or lacking pulsatile release of oestradiol and oxytocin or expressing high or low FSH concentrations 24-36 $\mathrm{h}$ after $P G$.

$\ddagger$ Data are only given for 4 heifers due to possible displacement of the vena cava catheter in one heifer during the experiment.

$\S$ The initial release of progesterone and oxytocin was not included in the calculation for progesterone and oxytocin during this time period.

${ }^{*} P<0.01$ compared with $\mathrm{LH}$ value.

Within rows, means with a superscript differ significantly from those without: ${ }^{a} P<0.05,{ }^{b} P<0.01$. 
the pulse frequency abruptly increased $(P<0.01)$ approximately 4 -fold while basal concentrations and pulse amplitude increased $(P<0.01)$ about $2-3$-fold compared to control values. LH concentrations remained elevated for the duration of the bleeding periods (Table 1; Text-figs $1 \& 2)$.

\section{Oestradiol}

Low-amplitude pulses with a long interpulse interval $(250 \mathrm{~min})$ were detected only in 3 heifers during the control period. The pulse frequency increased $(P<0.01)$ beginning $4-6 \mathrm{~h}$ after PG (Table 1; Text-fig. 1). A major difference amongst these animals occurred 24-36 h after PG: one heifer continued to exhibit a pulsatile secretion pattern (Text-fig. 1) whereas it ceased in the other 2 animals (Text-fig. 2b). In addition, pulses were detected in one animal that had had no detectable pulses up to $12 \mathrm{~h}$ after PG (Text-fig. 2a). Following PG there was a slight increase $(P<0.05)$ in mean concentrations in heifers with detectable pulses of oestradiol, but pulse amplitude did not increase from that observed during the control period (Table 1). Pulses of oestradiol were secreted after or concomitantly with pulses of LH (Text-fig. 1).

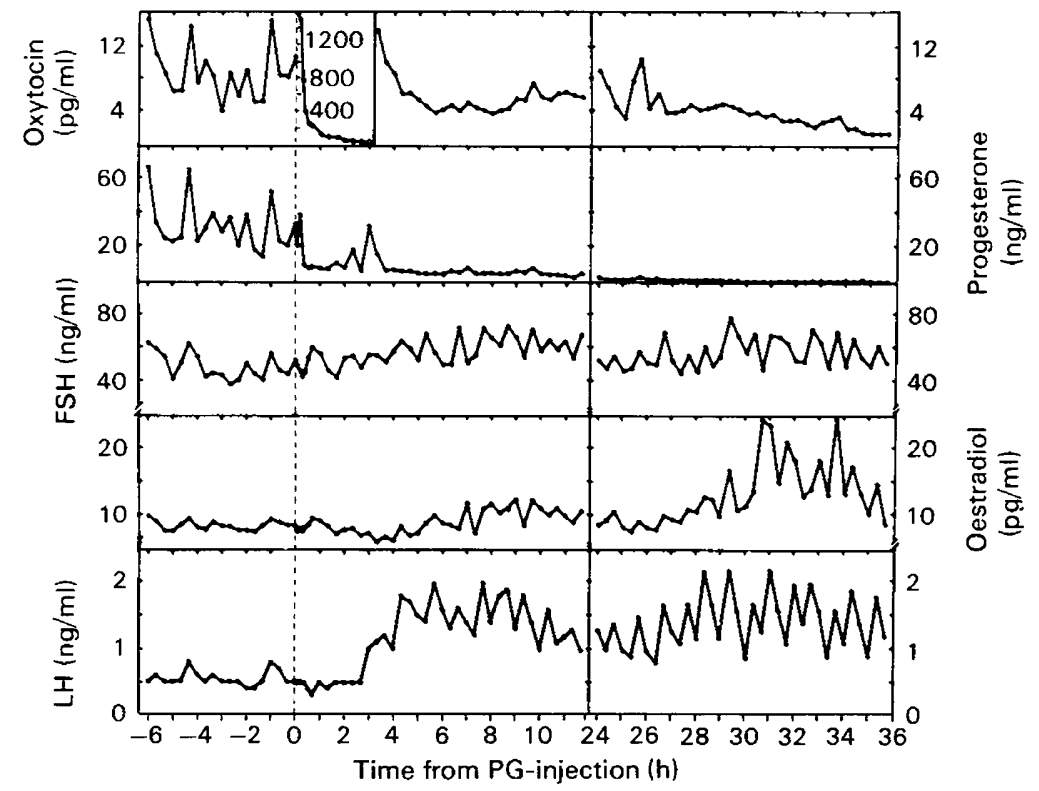

Text-fig. 1. Hormone profiles from vena cava (oestradiol, progesterone and oxytocin) and jugular vein (LH and FSH) blood samples collected at 5-20-min intervals from -6 to 12 and 24 to $36 \mathrm{~h}$ after an injection of a PG analogue on Day 12 (mid-luteal phase) of the oestrous cycle in Cow $\mathrm{K}$. Note that the scale for oxytocin is 100 times expanded initially after PG. This is an example of increasing and pulsing oestradiol secretion from 4 to 12 and 24 to $36 \mathrm{~h}$ after PG.

FSH

Pulses of FSH occurred at the same times as the LH pulses, but during the control period separate FSH pulses were also observed (Text-figs $1 \& 2)$, resulting in a shorter $(P<0.01)$ interpulse interval compared to that of LH (Table 1). Beginning 1-3 h after PG the interpulse interval decreased $(P<0.01)$ an average of $30 \mathrm{~min}$ from that observed during the control period and was similar to the LH interpulse interval. However, in contrast to LH, basal concentrations and pulse amplitude did not change significantly $(P>0.05) 0-12 \mathrm{~h}$ after PG relative to control values (Table 1). Mean and basal concentrations and pulse amplitude decreased $(P<0.05)$ in 3 


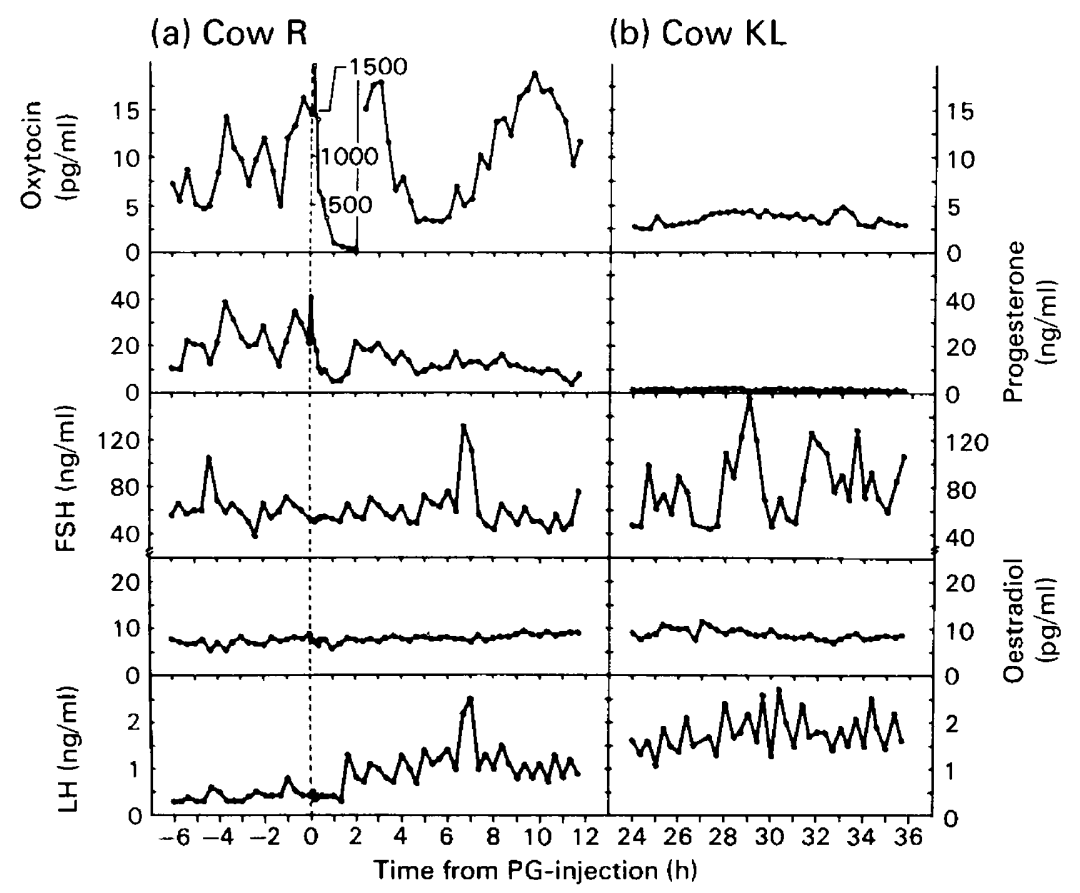

Text-fig. 2. Hormone profiles from -6 to $12 \mathrm{~h}$ (a) and 24-36 h (b) after PG in 2 cows. See Textfig. 1 legend for details in experimental procedure. These are examples for a non-pulsing oestradiol secretion pattern after PG. Cow KL had expressed oestradiol-17 $\beta$ pulses $0-12 \mathrm{~h}$ after PG.

heifers 24-36 $\mathrm{h}$ after PG (Table 1) while in the other 2 heifers there was no significant change, although there appeared to be an increase in pulse amplitude in one of the heifers (Text-fig. $2 b$ ).

\section{Progesterone}

During the control period high-amplitude pulses of progesterone either followed or were secreted concomitantly with LH/FSH and separate FSH pulses (Text-figs 1 \& 2), resulting in an interpulse interval similar to that observed for FSH (Table 1). Progesterone concentrations increased $(P<0.01)$ in all heifers $5-10 \mathrm{~min}$ after PG but then decreased $(P<0.01) 67 \%$ by $20 \mathrm{~min}$ with no pulses being observed for 2-3 h thereafter (Text-figs $1 \& 2 \mathrm{a}$ ). This reduction in progesterone concentrations was followed by an increase $(P<0.05)$ that occurred at the same time as the increase in frequency of $\mathrm{LH}$ and FSH pulses and lasted an average of $3.3 \pm 1.5 \mathrm{~h}$, after which time a steady decline was observed. Pulses were generally not observed $24-36 \bar{h}$ after PG (Text-figs $1 \&$ $2 \mathrm{~b})$ and basal concentrations were lower $(P<0.05)$ than at any other time during the experiment (Table 1).

\section{Oxytocin}

Pulses of oxytocin in vena cava blood occurred concomitantly with pulses of progesterone during the control period (Text-figs $1 \& 2 \mathrm{a}$ ) except for one animal which had relatively low vena cava oxytocin concentrations (Table 1 ). Oxytocin concentrations in the vena cava increased in all heifers $(P<0.01)$ to maximum concentrations within 5-10 min after PG and then decreased steadily over a $3-5$ h period (Text-figs 1,2 a \& 3a). Concentrations in the jugular vein increased ( $P$ $<0.01) 10-20 \mathrm{~min}$ after PG but were an average of $66 \%$ less than the maximum concentrations 
observed in the vena cava (Text-fig. 3a). Mean concentrations were lowest $(P<0.01) 24-36 \mathrm{~h}$ after PG and only a few low-amplitude pulses were observed (Text-figs $1 \& 2 b$ ).

\section{Prolactin}

Pulses of prolactin were detected but were not consistently related to pulses of any other hormone and varied greatly between heifers during the control period (data not shown). Contrary to these patterns mean concentrations increased $(P<0.01) 10-20 \mathrm{~min}$ after PG and then decreased steadily for 3-5 h (Text-fig. 3b). Maximum concentrations were consistently higher and appeared 5-10 min earlier in the jugular vein compared to the vena cava (Text-fig. $3 \mathrm{~b}$ ).

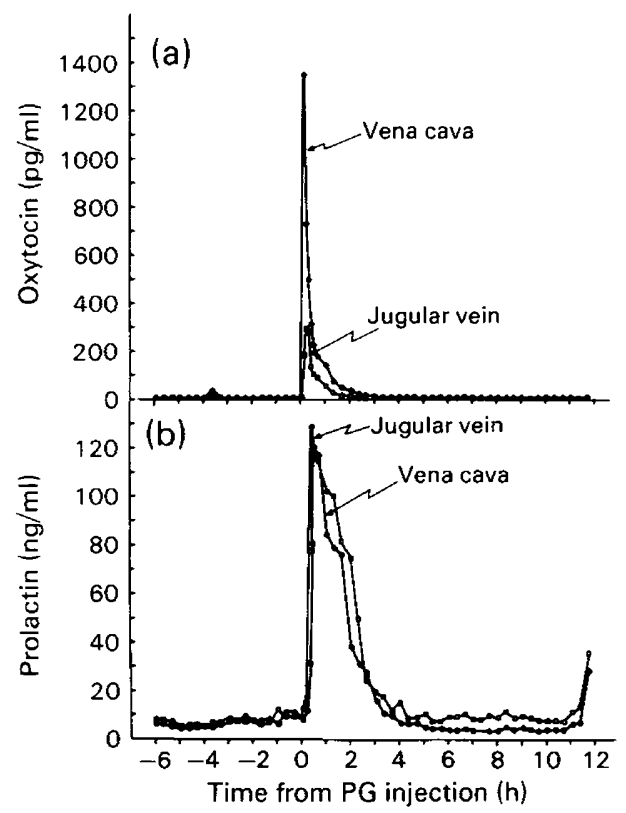

Text-fig. 3. Profiles of (a) oxytocin and (b) prolactin from vena cava ( $\odot$ ) and jugular vein ( $\square$ ) blood samples from -6 to $12 \mathrm{~h}$ after PG in Cow KL. See Text-fig. 1 legend for details of experimental procedure.

\section{Discussion}

The immediate increase in progesterone concentrations 5-10 min after a luteolytic dose of a PG analogue is in agreement with an earlier report by Lamond, Tomlinson, Drost, Henricks \& Jöchle (1973) and may be the result of initial concentrations of PG exerting a stimulatory effect on the corpus luteum (Hansel, Hixon, Shemesh \& Tobey, 1976). The subsequent decrease in progesterone concentrations after PG in the present study confirms and expands results of Lamond et al. (1973), Schams \& Karg (1982) and Milvae \& Hansel (1983). The reduction (67\%) in progesterone concentrations in the vena cava that occurred $20 \mathrm{~min}$ after PG and lasted for $1-3 \mathrm{~h}$ may be due primarily to a decrease in blood flow to the corpus luteum and/or a direct effect on the luteal cells. Nett \& Niswender (1981) reported that blood flow to the corpus luteum is reduced $90 \%$ within $2 \mathrm{~h}$ of a luteolytic dose of PG in ewes. In addition, Weston \& Hixon (1980) observed a $40 \%$ decrease in progesterone concentrations in corpora lutea of cows within $2 \mathrm{~h}$ of a PG injection. It does not seem likely that the initial reduction in progesterone concentrations was due to a decrease in the number of luteal LH receptors since progesterone concentrations decrease $12-15 \mathrm{~h}$ before the reduction in 
LH receptor concentrations in cows (Spicer et al., 1981). Furthermore, the in-vitro steroidogenic response of bovine corpora lutea to LH appears to be maintained for up to $8 \mathrm{~h}$ after PG (Weston \& Hixon, 1980).

The frequent pulses of progesterone that were detected in all heifers beginning $2-3 \mathrm{~h}$ after PG occurred after or concomitantly with the increase in pulses of LH/FSH. Therefore, it is probable that sufficient numbers of LH and FSH receptors were present $3-8 \mathrm{~h}$ after PG to respond to the increase in frequency of LH/FSH pulses that occurred during this time.

The abrupt, 3-fold, increase in mean LH concentrations 1-3 h after PG is in agreement with earlier studies by Louis, Stellflug, Tucker \& Hafs (1974b), Stellflug, Louis, Gorewit, Oxender \& Hafs (1977) and Milvae \& Hansel (1983). An increase in LH concentrations does not occur if PG is administered when a functional corpus luteum is not present (Hafs, Louis, Stellflug, Convey \& Britt, 1975; Furr, Cooper, Jackson, Hart \& Pope, 1981). Therefore, since progesterone is a potent inhibitor of LH secretion (Convey, Beck, Neitzel, Bostwick \& Hafs, 1977; Ireland \& Roche, 1982a) the increase in LH concentrations after a luteolytic injection of PG in cows is probably the result of a reduction in negative feedback due to the decreasing progesterone concentrations. However, the increased LH pulse frequency after PG cannot be explained solely by the reduction in progesterone concentrations since the 60 -min interpulse interval that was observed is actually shorter than the interpulse interval in short-term ovariectomized cows (Schallenberger \& Peterson, 1982) and ewes (Karsch, Foster, Bittman \& Goodman, 1983). Therefore, low oestradiol concentrations in the absence of high progesterone concentrations probably contributed to the rapid LH pulse frequency observed in the present study.

After PG, pulses of LH were generally secreted concomitantly with pulses of FSH which resulted in similar interpulse intervals. However, additional pulses of FSH were secreted during the control period (when progesterone concentrations were elevated), resulting in a much shorter interpulse interval for FSH than LH (Walters et al., 1984). During the periovulatory phase of the oestrous cycle, when oestradiol (and LH) concentrations are high, basal FSH concentrations decrease in cows due to a reduction in pulse amplitude at a time when FSH frequency is actually at its highest (Walters \& Schallenberger, 1984). The decrease in mean FSH concentrations and FSH amplitude in one group of heifers $24-36 \mathrm{~h}$ after PG may therefore be due to the higher oestradiol concentrations present in these animals at that time. However, the possibility that another hormone, such as inhibin (Henderson \& Franchimont, 1981), may have caused the differences in FSH concentrations 24-36 h after PG cannot be excluded.

Pulses of oestradiol are secreted in response to pulses of LH during the luteal and periovulatory phases of the oestrous cycle in cows (Walters et al., 1984; Walters \& Schallenberger, 1984). The largest follicle generally regresses following an injection of PG on Day 8 or 9 of the oestrous cycle of the cow (J. J. Ireland, personal communication). This follicle becomes unresponsive to LH stimulation probably due to a lack of LH receptors (Ireland \& Roche, 1982b). This would explain the large variation between and within heifers with regard to the secretion pattern of oestradiol after PG and the occurrence of oestrus. Since follicular growth and regression occur continuously throughout the oestrous cycle of the cow (Rajakoski, 1960; Schams, Schallenberger, Hoffmann \& Karg, 1977; Matton, Adelakoun, Couture \& Dufour, 1981), it is concluded that the stage of follicular development at the time of $P G$ injection probably determines how long it takes for a preovulatory follicle to develop and to produce sufficient oestradiol to initiate oestrus and the LH surge (Ireland \& Roche, 1982a; Walters \& Schallenberger, 1984).

Prolactin was secreted from the pituitary after PG (Louis et al., 1974b; Furr et al., 1981; Schams \& Karg, 1982) since high concentrations were detected earlier in the jugular vein than in the vena cava.

Oxytocin is present in high concentrations in the corpus luteum of the ewe and cow (Wathes \& Swann, 1982; Schams et al., 1983a) and is secreted from the corpus luteum into the ovarian vein (Flint \& Sheldrick, 1983; Walters et al., 1984). Oxytocin is known to be luteolytic in the cow if it is given early in the oestrous cycle (Armstrong \& Hansel, 1959) and if the uterine horn adjacent to the 
ovary bearing the corpus luteum is present (Ginther, Woody, Mahajan, Janakiraman \& Casida, 1967). Also, active and passive immunization against oxytocin prolongs the oestrous cycle of ewes (Sheldrick, Mitchell \& Flint, 1980; Schams, Prokopp \& Barth, 1983b). Almost no oxytocin is released after PG in ovariectomized or follicular-phase cows (D. Schams, unpublished data). Therefore, the release of oxytocin from the corpus luteum in cows in response to PG and the stimulation of PG secretion from the uterus by exogenous oxytocin (Newcomb et al., 1977; Milvae \& Hansel, 1980) indicate that a positive feedback system may function between the ovary and the uterus to cause regression of the corpus luteum. This might act via the mechanisms proposed by Roberts, McCracken, Gavagan \& Soloff (1976). However, this does not necessarily mean that PGF- $2 \alpha$ is being transferred directly from the uterus to the ovary. Milvae \& Hansel (1980) demonstrated that PGF concentrations in the uterine vein increased following an injection of oxytocin, but there was no corresponding increase in PGF concentrations in the ovarian artery. It is therefore possible that the feedback system between the ovary and the uterus may act through the primary PG metabolite (Milvae \& Hansel, 1983), the systemic circulation or some other unidentified link.

D.L.W. was a postdoctoral fellow of the Alexander von Humboldt-Stiftung, Bonn, FRG. This study was supported by the Deutsche Forschungsgemeinschaft, Bonn. We thank the NIAMDD for supplying us with NIH-FSH-B1 and NIH-P-B3 and J. Redl and P. Hempe for expert technical assistance.

\section{References}

Armstrong, D.T. \& Hansel, W. (1959) Alteration of the bovine estrous cycle with oxytocin. J. Dairy Sci. 42, 533-542.

Convey, E.M., Beck, T.W., Neitzel, R.R., Bostwick, E.F. \& Hafs, H.D. (1977) Negative feedback control of bovine serum luteinizing hormone (LH) concentration from completion of the preovulatory LH surge until resumption of luteal function. J. Anim. Sci. 45, $792-796$.

Flint, A.P.F. \& Sheldrick, E.L. (1983) Evidence for a systemic role of ovarian oxytocin in luteal regression in sheep. J. Reprod. Fert. 67, 215-225.

Furr, B.J.A., Cooper, M.J., Jackson, P.S., Hart, I.C. \& Pope, G.S. (1981) Effects of cloprostenol and prostaglandin $F_{2 \alpha}$ on secretion of follicle stimulating hormone, luteinizing hormone, prolactin, growth hormone, thyroxine and cortisol in heifers. Acta vet. scand., Suppl. 77, 55-69.

Ginther, O.J., Woody, C.O., Mahajan, S., Janakiraman, K. \& Casida, L.E. (1967) Effect of oxytocin administration on the oestrous cycle of unilaterally hysterectomized heifers. J. Reprod. Fert. 14, 225-229.

Hafs, H.D., Louis, T.M., Stellfug, J.N., Convey, E.M. \& Britt, J.H. (1975) Blood LH after PGF $2 a$ in diestrous and ovariectomized cattle. Prostaglandins 10, 10011009.

Hansel, W. \& Snook, R.B. (1970) Pituitary ovarian relationships in the cow. J. Dairy Sci. 53, 945961.

Hansel, W., Hixon, J., Shemesh, M. \& Tobey, D. (1976) Concentrations and activities of prostaglandins of the $\mathrm{F}$ series in bovine tissue, blood and milk. J. Dairy Sci. 59, 1353-1365.

Henderson, K.M. \& Franchimont, P. (1981) Regulation of inhibin production by bovine ovarian cells in vitro. $J$. Reprod. Fert. 63, 431-442.
Hoffmann, B., Kyrein, H.J. \& Ender, M.L. (1973) An efficient procedure for the determination of progesterone by radioimmunoassay applied to bovine peripheral plasma. Hormone Res. 4, 302-310.

Ireland, J.J. \& Roche, J.F. (1982a) Effect of progesterone on basal LH and episodic LH and FSH secretion in heifers. J. Reprod. Fert. 64, 295-302.

Ireland, J.J. \& Roche, J.F. (1982b) Development of antral follicles in cattle after prostaglandin-induced luteolysis: changes in serum hormones, steroids in follicular fluid, and gonadotropin receptors. Endocrinology 111, 2077-2086.

Karg, H., Hoffmann, B. \& Schams, D. (1970) Luteinizing hormone, prolactin and progesterone relationships "in vivo" (data from the cow). Excerpta Medica Int. Congr. Ser. 219, 691-698.

Karsch, F.J., Foster, D.L., Bittman, E.L. \& Goodman, R.L. (1983) A role for estradiol in enhancing luteinizing hormone pulse frequency during the follicular phase of the estrous cycle of sheep. Endocrinology 113, 1333-1339.

Lamond, D.R., Tomlinson, R.V., Drost, M., Henricks, D.M. \& Jöchle, W. (1973) Studies of prostaglandin $\mathrm{F}_{2 \alpha}$ in the cow. Prostaglandins 4, 269-284.

Louis, T.M., Hafs, H.D. \& Morrow, D.A. (1974a) Intrauterine administration of prostaglandin $F_{2 a}$ in cows: progesterone, estrogen, LH, estrus and ovulation. J. Anim. Sci. 38, 347-353.

Louis, T.M., Stellfiug, J.N., Tucker, H.A. \& Hafs, H.D. (1974b) Plasma prolactin, growth hormone, luteinizing hormone and glucocorticoids after prostaglandin $\mathrm{F}_{2 \alpha}$ in heifers. Proc. Soc. exp. Biol. Med. 147, 128-133.

Matton, P., Adelakoun, V., Couture, Y. \& Dufour, J.J. (1981) Growth and replacement of the bovine ovarian follicles during the estrous cycle. J. Anim. Sci. 52, 813-820. 
Milvae, R.A. \& Hansel, W. (1980) Concurrent uterine venous and ovarian arterial prostaglandin $F$ concentrations in heifers treated with oxytocin. $J$. Reprod. Fert. 60, 7-15.

Milvae, R.A. \& Hansel, W. (1983) Luteolytic effect of 13,14-dihydro-PGF- $2 \alpha$ in heifers. J. Reprod. Fert. 67 , 203-207.

Nett, T.M. \& Niswender, G.D. (1981) Luteal blood flow and receptor for $\mathrm{LH}$ during $\mathrm{PGF}_{2 \alpha}$-induced luteolysis: production of $\mathrm{PGE}_{2}$ and $\mathrm{PGF}_{2 \alpha}$ during early pregnancy. Acta vet. Scand., Suppl. 77, 117-130.

Newcomb, R., Booth, W.D. \& Rowson, L.E.A. (1977) The effect of oxytocin treatment on the levels of prostaglandin $\mathrm{F}$ in the blood of heifers. J. Reprod. Fert. 49, 17-24.

Rajakoski, E. (1980) The ovarian follicular system in sexually mature heifers with special reference to season, cyclical and left-right variations. Acta endocr., Copenh., Suppl. 52, 1-68.

Roberts, J.S., McCracken, J.A., Gavagan, J.E. \& Soloff, M.S. (1976) Oxytocin-stimulated release of prostaglandin $F_{2 a}$ from ovine endometrium in vitro: correlation with estrous cycle and oxytocin-receptor binding. Endocrinology 99, 1107-1114.

Schallenberger, E. \& Peterson, A.J. (1982) Effect of ovariectomy on tonic gonadotrophin secretion in cyclic and post-partum dairy cows. J. Reprod. Fert. 64, 47-52.

Schams, D. (1983) Oxytocin determination by radioimmunoassay. III. Improvement to subpicogram sensitivity and application to blood levels in cyclic cattle. Acta endocr., Copenh. 103, 180-183.

Schams, D. \& Karg, H. (1969a) Radioimmunologische LH-Bestimmung in Blutserum vom Rind unter besonderer Berücksichtigung des Brunstzyklus. Acta endocr., Copenh. 61, 96-103.

Schams, D. \& Karg, H. (1969b) Radioimmunologische Bestimmung von Prolaktin im Blutserum vom Rind. Milchwissenschaft 24, 263-265.

Schams, D. \& Karg, H. (1982) Hormonal response following treatment with different prostaglandin analogues for estrous cycle regulation in cattle. Theriogenology 17, 499-513.

Schams, D. \& Schallenberger, E. (1976) Heterologous radioimmunoassay for bovine follicle-stimulating hormone and its application during the oestrous cycle in cattle. Acta endocr., Copenh. 81, 461-473.
Schams, D., Schallenberger, E., Hoffmann, B. \& Karg, H. (1977) The oestrous cycle of the cow: hormonal parameters and time relationships concerning oestrus, ovulation, and electrical resistance of the vaginal mucus. Acta endocr., Copenh. 86, 180-192.

Schams, D., Walters, D.L., Schallenberger, E., Bullermann, B. \& Karg, H. (1983a) Ovarian oxytocin in the cow. Acta endocr., Copenh., Suppl. 253, 147 Abstr. 164.

Schams, D., Prokopp, S. \& Barth, D. (1983b) The effect of active and passive immunization against oxytocin on ovarian cyclicity in ewes. Acta endocr., Copenh. 103, 337-344.

Sheldrick, E.L., Mitchell, M.D. \& Flint, A.P.F. (1980) Delayed luteal regression in ewes immunized against oxytocin. J. Reprod. Fert. 59, 37-42.

Spicer, L.J., Ireland, J.J. \& Roche, J.F. (1981) Changes in serum LH, progesterone, and specific binding of ${ }^{125} \mathrm{I}-\mathrm{hCG}$ to luteal cells during regression and development of bovine corpora lutea. Biol. Reprod. 25, 832-841.

Stellfug, J.N., Louis, T.M., Gorewit, R.C., Oxender, W.D. \& Hafs, H.D. (1977) Luteolysis induced by prostaglandin $F_{2 \alpha}$ before and after hysterectomy in heifers. Biol. Reprod. 17, 535-540.

Walters, D.L. \& Schallenberger, E. (1983) Kurzzeitsekretion von Östradiol-17 $\beta$ und Progesteron beim RindVergleich der Konzentrationen im Blutplasma der V. cava und V. jugularis. Wien. tierärztl. Mschr. 70, 247248.

Walters, D.L. \& Schallenberger, E. (1984) Pulsatile secretion of gonadotrophins, ovarian steroids and ovarian oxytocin during the periovulatory phase of the oestrous cycle in the cow. J. Reprod. Fert. 71, 503512.

Walters, D.L., Schams, D. \& Schallenberger, E. (1984) Pulsatile secretion of gonadotrophins, ovarian steroids and ovarian oxytocin during the luteal phase of the oestrous cycle in the cow. J. Reprod. Fert. 71, $479-491$.

Wathes, D.C. \& Swann, R.W. (1982) Is oxytocin an ovarian hormone? Nature, Lond. 297, 225-227.

Weston, P.G. \& Hixon, J.E. (1980) Effects of in vivo prostaglandin $F_{2 \alpha}$ administration on in vitro progesterone synthesis by bovine corpora lutea. Biol. Reprod. 22, 259-268. 